\title{
Characterization of Garden Cress Mucilage and its Prophylactic Effect Against Indomethacin-Induced Enter- Colitis in Rats
}

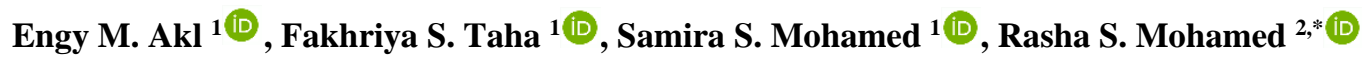 \\ 1 Department of Fats and Oils, National Research Centre, Dokki, Cairo, Egypt; engy_akl@yahoo.com (E.M.A.); \\ fs_taha@yahoo.com (F.S.T.); drsamira2009@yahoo.com (S.S.M.); \\ 2 Department of Nutrition and Food Sciences, National Research Centre, Dokki, Cairo, Egypt; smarasha2005@yahoo.com \\ (R.S.M.); \\ * Correspondence: smarasha2005@yahoo.com;
}

Scopus Author ID 57204599407

Received: 20.01.2021; Revised: 20.02.2021; Accepted: 24.02.2021; Published: 2.03.2021

\begin{abstract}
The utilization of industrial waste such as oil industry waste in the production of natural nutraceuticals is a very beneficial issue. So, the current study was established to assess the characteristics of the mucilage extracted from garden cress seeds meal and evaluate its efficacy in the protection against enter-colitis. A defatted powder meal of garden cress seeds was dissolved in distilled water to extract the mucilage either by heating at $80^{\circ} \mathrm{C}$ or by ultrasonication. Functional and chemical characteristics of the two types of mucilage were assessed. Rats received oral administration of the mucilage extracted by ultrasonication, which afforded the most promising antioxidant activity, for two weeks before and during the 7 days of oral administration by indomethacin $(6 \mathrm{mg} / \mathrm{kg} / \mathrm{day})$. Compared with the rats injected with indomethacin without the pre-treatment with the mucilage, rats administrated with the mucilage showed a decrease in the erythrocyte sedimentation rate (ESR), intestinal tumor necrosis factor- $\alpha$ (TNF- $\alpha$ ), and plasma lactate dehydrogenase (LDH) activity. Also, rats administered with the mucilage recorded lower intestinal malodealdehyde (MDA) and higher intestinal reduced glutathione (GSH) compared to those of rats injected with indomethacin without the pre-treatment with the mucilage. It can be concluded that the mucilage extracted from garden cress seeds meal can be considered as a natural nutraceutical with potent antioxidant activity exhibiting protective effect against enter-colitis.
\end{abstract}

Keywords: garden cress; mucilage; inflammatory bowel disease; indomethacin.

(C) 2021 by the authors. This article is an open-access article distributed under the terms and conditions of the Creative Commons Attribution (CC BY) license (https://creativecommons.org/licenses/by/4.0/).

\section{Introduction}

Inflammatory bowel disease (IBD) is described by discontinuous inflammation in the gastrointestinal tract. The prevalence of IBD, including ulcerative colitis (UC) and Crohn's disease (CD), has increased over the past few decades [1]. Weight loss, diarrhea, hematochezia, vomiting, and pain are among the most common IBD clinical symptoms. Amino-salicylates, immunosuppressive agents, and corticosteroids are the most common medical therapies of IBD, but they exert several side effects and lead to mood disturbance, type 2 diabetes, obesity, acne, insomnia, avascular necrosis, and skin atrophy [2]. Non-steroidal anti-inflammatory drugs (NSAIDs), which are extensively used without medical guidance, are considered one of the main inducers of IBD [3]. 
Nie et al. [4] declared that non-starch polysaccharides (NSPs), including gum, may be promising agents for protection against IBD via several mechanisms such as anti-inflammation, stimulating the immune system, alteration of the gut microbiota, generation of the short-chain fatty acids (SCFAs), anti-oxidative stress go together by inflammation and the diminution of the absorption of toxins.

Garden cress (Lepidium sativum) seeds are seeds that are when soaked in water and produce a viscous gel due to its high content of colloidal substances [5]. L-arabinose, D-xylose, D-galactose, L-rhamnose, D-galacturonic acid, and 4-O-methyl-D-glucuronic acid are the compounds with the highest percentage of the Lepidium sativum gel composition, in addition to the presence of other compounds with a lower percentage that includes D-glucose and mannose [6]. Ahmad et al. [7] reported that polysaccharides extracted from garden cress reduced the level of tumor necrosis factor-alpha (TNF- $\alpha$ ) in mice' plasma. Therefore, in the present study, garden cress mucilage was extracted with two different methods and assessed for its functional and chemical properties in addition to its efficacy in the protection against enter-colitis induced by indomethacin in rats.

\section{Materials and Methods}

\subsection{Materials and chemicals.}

Garden cress seeds were brought from a local market in Egypt. Chemicals and pure reagents were purchased from Sigma Chemical Companies (Sigma-Aldrich, St. Louis, MO, USA). Indomethacin was obtained from a local pharmacy in Egypt.

\subsection{Extraction of the garden cress mucilage.}

Garden cress seeds were grounded then subjected to defatting using a soxhlet apparatus and n-hexane as a defatting solvent. The defatted meal was spread on a tray to dry than the ground to obtain a fine powder. The polysaccharide extracted by two methods: First, by soaking in hot water (MHW), $300 \mathrm{~g}$ garden cress meal was stirred well by electric stirrer in 9 liters distilled water then soaked for 24 hours at $80^{\circ} \mathrm{C}$. Second, by the aid of ultrasonic bath (MUS), $300 \mathrm{~g}$ garden cress meal was stirred well by electric stirrer in 9 liters distilled water then soaked in an ultrasonic bath for two hours at room temperature. Both extracts were centrifuged for $30 \mathrm{~min}$ at $3000 \mathrm{xg}$ then the supernatant collected and concentrated by rotary evaporator at $60^{\circ} \mathrm{C}$. The polysaccharide precipitated with ethanol's addition to the final extract then freeze-dried by (Crest Alpha 1-4 LSC plus Germany). The freeze-dried mucilage was sieved by 140 meshes then kept in a refrigerator until used.

\subsection{Functional properties of the two types of extracted mucilage.}

2.3.1. Bulk density.

Bulk density was estimated according to Taha and Ibrahim [8].

2.3.2. Water-Holding Capacity (WHC) and Oil-Holding Capacity (OHC).

Water-Holding Capacity (WHC) and Oil-Holding Capacity (OHC) were determined as described by [9] and expressed as percentage $g$ of water or oil held/g sample. 


\subsubsection{Emulsifying capacity (EC).}

$30 \mathrm{ml}$ of 1:100 and $2 \mathrm{ml}$ corn oil were added according to Shahidi et al. [10]. The emulsifying capacity was calculated as a ratio of emulsified versus total volume.

\subsubsection{Foaming properties.}

Foaming properties, including foaming capacity (FC) and foam stability (FS), were determined by the method of Shahidi et al. [10] with the minor modifications made by Wang et al. [11]. Foaming capacity was calculated using the following equation: $\mathrm{FC} \%=\left(\mathrm{V}-\mathrm{V}_{0} / \mathrm{V}_{0}\right)$ $\times 100$

Where $\mathrm{V}$ and $\mathrm{V}_{0}$ are the volumes immediately measured after whipping and before whipping, respectively.

\subsubsection{Apparent viscosity.}

Apparent viscosity was measured at different temperatures using a Brookfield digital viscometer (Model DV-II, Canada) fitted with spindle 3 at $200 \mathrm{rpm}$ with $1 \%$ (w/v), and apparent viscosity was expressed as cp and different rpm fitted with spindle 0 .

\subsection{Chemical composition of the two types of extracted mucilage.}

Moisture, Protein, and Ash contents were estimated according to AOAC [12]. The functional groups of the extracted garden cress mucilage were determined using Fourier transform infrared (FTIR) spectra in the range of $500-4000 \mathrm{~cm}^{-1}$ on Shimadzu 8400 S FTIR spectrophotometer using the $\mathrm{KBr}$ disk technique. Minerals contents were determined using a flame atomic absorption spectrometer (Agilent Technologies); one g of each sample was placed in a clean crucible and placed in a furnace. The content was ashed at $650{ }^{\circ} \mathrm{C}$ for $10 \mathrm{~h}$ until a whitish-grey matter was obtained then cooled. $2 \mathrm{M} \mathrm{HCl}$ was added, then deionized water (completed to $20 \mathrm{~mL}$ ) was added and filtered then the filtrate was used for the metal assay. The amount of individual element was calculated by the obtained values following their standard curves, and the measurements were made at $589.6 \mathrm{~nm}(\mathrm{Na}), 766.5 \mathrm{~nm}(\mathrm{~K}), 239.9 \mathrm{~nm}(\mathrm{Ca})$, $202.6 \mathrm{~nm}(\mathrm{Mg}), 248.3 \mathrm{~nm}(\mathrm{Fe}), 279.5 \mathrm{~nm}(\mathrm{Mn}), 324.7 \mathrm{~nm}(\mathrm{Cu})$ and $213.9 \mathrm{~nm}(\mathrm{Zn})$.

\subsection{Cytotoxic effect on human normal fibroplast cell line (BJ1).}

Mitochondrial-dependent reduction of yellow MTT (3-(4,5-dimethylthiazol-2-yl)-2,5diphenyl tetrazolium bromide) to purple formazan was used to assess the cell viability [13].

In a sterile zone, using a Laminar flow cabinet biosafety class II level (Baker, SG403INT, Sanford, ME, USA), cells were suspended in DMEM-F12 medium, 1\% mixture of antibiotic-antimycotic (10,000U/ml Potassium Penicillin, 10,000 $\mathrm{gg} / \mathrm{ml}$ Streptomycin Sulfate, and $25 \mu \mathrm{g} / \mathrm{ml}$ Amphotericin B) and L-glutamine (1\%) at $37{ }^{\circ} \mathrm{C}$ under $5 \% \mathrm{CO}_{2}$

Cells were cultured for 10 days in batches. They were seeded $\left(10 \times 10^{3}\right.$ cells/well $)$ in a wells-microtiter plastic plate, contained fresh complete growth medium, at $37^{\circ} \mathrm{C}$ for $24 \mathrm{~h}$ under $5 \% \mathrm{CO} 2$ through a water-jacketed Carbon dioxide incubator (Sheldon, TC2323, Cornelius, OR, USA). The medium was removed, and a fresh medium (without serum) was inserted. Cells were incubated for $48 \mathrm{~h}$ alone as a negative control and with different concentrations of a sample (100-50-25-12.5-6.25-3.125- 1.56 and $0.78 \mu \mathrm{g} / \mathrm{ml})$, then the medium was removed and $40 \mathrm{ul} \mathrm{MTT} \mathrm{salt}(2.5 \mu \mathrm{g} / \mathrm{ml})$ were added to each well and incubated for $4 \mathrm{~h}$ at $37^{\circ} \mathrm{C}$ under $5 \%$ 
$\mathrm{CO} 2$. Solution $(200 \mu \mathrm{L})$ of sodium dodecyl sulfate $(10 \%)$ was added to each well to stop the reaction, then wells were incubated overnight at $37^{\circ} \mathrm{C}$. DOX $(100 \mu \mathrm{g} / \mathrm{ml})$, which gives $100 \%$ lethality under the same conditions [14], was used as a positive control.

A microplate multi-well reader (Bio-Rad Laboratories Inc., model 3350, Hercules, California, USA) was used to measure the absorbance at $595 \mathrm{~nm}$. The percentage of change in viability was calculated using the following equation:

((Reading of extract/Reading of negative control) -1$) \times 100$

\subsection{Evaluation of the prophylactic effect against indomethacin-induced enter-colitis.}

2.6.1. Animals.

Male Wistar rats (14 weeks old) of $234.44 \pm 14.2 \mathrm{~g}$ as mean \pm SD were taken from the animal house of National Research Centre, Cairo, Egypt. Each rat was housed in a stainless steel cage under standard laboratory conditions $\left(23-25{ }^{\circ} \mathrm{C}, 12 \mathrm{~h}\right.$ light/dark cycle) and free access to diet and water. According to the Medical Research Ethics Committee, National Research Centre, Cairo, Egypt, this study has been carried out and followed the recommendations of the National Institutes of Health Guide for Care and Use of Laboratory Animals (Publication No. 85-23, revised 1985).

\subsubsection{Animals' diet.}

Balanced diet (12\% casein as a source of protein, $10 \%$ corn oil, $10 \%$ sucrose, $58.5 \%$ maize starch, $5 \%$ fiber, $3.5 \%$ salt mixture, and $1 \%$ vitamin mixture), salt, and vitamin mixtures were prepared according to AIN-93 [15].

\subsubsection{Design of the animals' experiment.}

Eighteen rats were divided after one-week acclimatization into three groups $(n=6)$ as follows:

G1: The normal control group where rats were daily orally given distilled water.

G2: Indomethacin group (INDO) where the rats were treated orally with distilled water for two weeks then administered with indomethacin $(6 \mathrm{mg} / \mathrm{kg} / \mathrm{day})$ dissolved in $5 \%$ sodium bicarbonate for 7 days [3].

G3: Garden cress mucilage extracted by the aid of ultrasonic bath + indomethacin group (MUE+INDO) where rats were daily treated orally with garden cress mucilage $(100 \mathrm{mg} / \mathrm{Kg}$ b.w.) for two weeks before and during the 7 days administration of indomethacin $(6 \mathrm{mg} / \mathrm{kg} /$ day $)$ dissolved in 5\% sodium bicarbonate [3].

All rats were fed on a balanced diet all over the study period (three weeks). At the end of every week, total food intake and body weight gain were calculated. Total food intake and body weight gain were estimated after the end of the treatment period. Additionally, the feed efficiency ratio was calculated.

\subsubsection{Blood analysis.}

Twenty-four hours after the last administration of indomethacin, blood was collected from each rat under slight anesthesia. A portion of the whole blood was analyzed for erythrocyte sedimentation rate (ESR) and hemoglobin (Hb) according to Drabkin [16], and the 
remaining blood was centrifugated for $10 \mathrm{~min}$ at $1000 \mathrm{~g}$ and serum of each rat was kept under $-20{ }^{\circ} \mathrm{C}$ until used. Serum iron, total iron-binding capacity (TIBC), and lactate dehydrogenase (LDH) activity were determined according to Stookey [17], Betts and Stuart [18], and Zimmerman et al. [19], respectively.

\subsubsection{Hemoglobin of the intestinal flush.}

$\mathrm{Hb}$ concentration was assessed in the intestinal flush according to Crosby and Furth [20] and Schuck-Phan et al. [21]. A benzidine solution (1 mL) containing $1 \%(\mathrm{w} / \mathrm{w})$ of benzidine dihydrochloride in $90 \%(\mathrm{v} / \mathrm{v})$ of glacial acetic acid was added to a test tube. The intestinal flush $(0.02 \mathrm{~mL})$ was added, then $1 \mathrm{~mL}$ of $1 \%$ of hydrogen peroxide was added to the tube with mixing, and then a diluent containing $10 \%(\mathrm{v} / \mathrm{v})$ glacial acetic acid was placed. After $10 \mathrm{~min}$, the absorbance at $515 \mathrm{~nm}$ was measured by a spectrophotometer, and $\mathrm{Hb}$ concentration $(\mathrm{mg} / \mathrm{mL})$ was calculated using a standard curve.

\subsubsection{Small intestine homogenate analysis.}

Segments of each rat' small intestine were taken after the sacrificing and measured for their length. The small intestine homogenate was immediately analyzed for malondialdehyde (MDA), nitric oxide (NO), and reduced glutathione (GSH) according to Ohkawa et al. [22], Montgomery and Dymock [23], and Sedlak and Lindsay [24], respectively. Also, the tumor necrosis factor- $\alpha$ (TNF- $\alpha$ ) and superoxide dismutase (SOD) were determined using Eliza kits (SinoGeneclon Biotech Co., Ltd).

\subsection{Statistical analysis.}

Statistical analysis was done using SPSS version 21. The results were expressed as mean \pm standard error (SE) and analyzed statistically using a one-way analysis of variance (ANOVA) followed by Duncan test. The statistical significance of difference was taken as $P \leq$ 0.05 . Results of the chemical composition, function properties, and mineral contents of the two types of mucilage were analyzed statistically using a T-test and expressed as mean \pm standard deviation (SD).

\section{Results and Discussion}

It was evident from previous studies that the remnants of squeezing garden cress seeds can be used to produce products of high health value [25]. The current study indicated that the products of squeezing garden cress seeds could be exploited and converted from waste that requires disposal to products of biological value such as mucilage. Mucilage could be extracted from the whole mucilaginous seeds or from the meal with different methods, including hot water, microwaves, magnetic stirring, and ultrasounds [26, 27]. In the current study, mucilage of garden cress seeds was extracted by hot water and ultrasound aid. The characteristics of the two differently extracted types of mucilage were studied.

Figure 1 illustrates the soluble garden cress seeds in distilled water and the soluble mucilage of garden cress meal in water. The freeze-dried powders of the two extracted mucilage types were brownish-white in color, as shown in Figure 2. Both types of the extracted mucilage (either with hot water or with the aid of an ultrasonic bath) were approximately the same in color. 


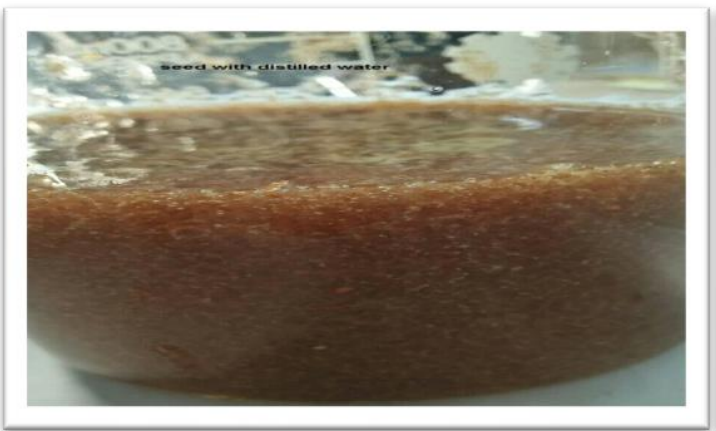

A. Soluble Seeds

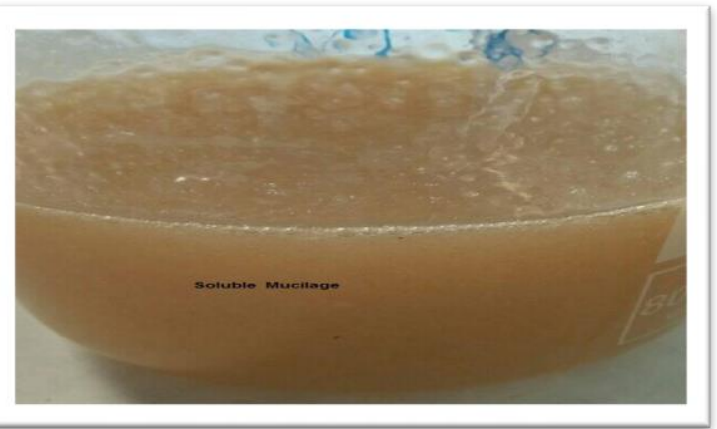

B. Soluble Mucilage

Figure 1. Soluble garden cress seeds (A) and soluble mucilage (B).

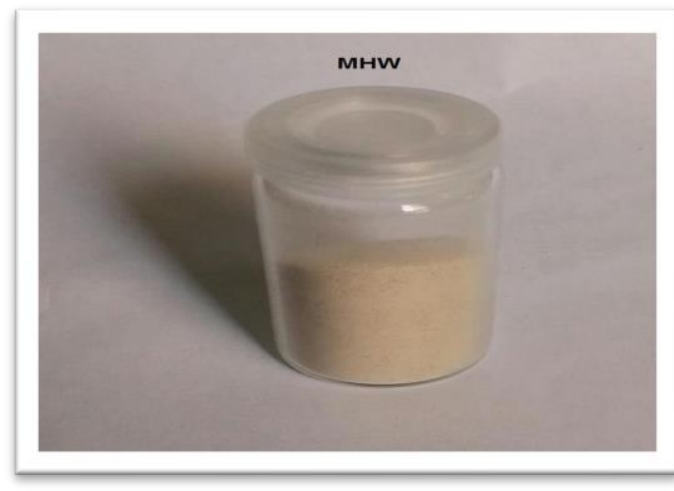

A. MHW

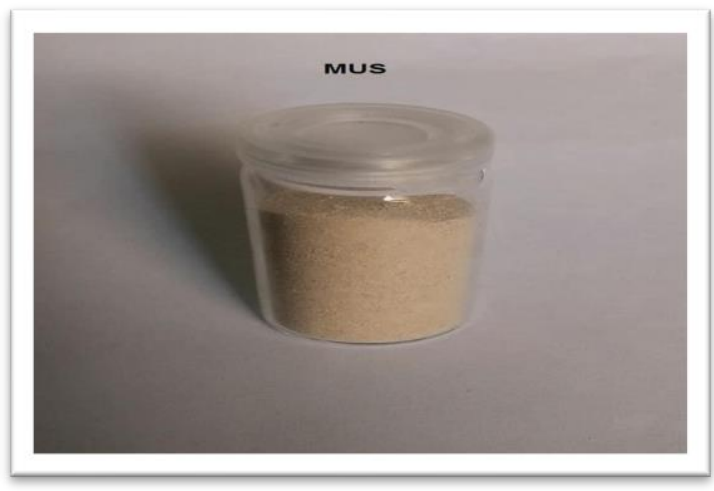

B. MUS

Figure 2. Powder of mucilage extracted by hot water (MHW) (A) and Powder mucilage extracted with the aid of ultrasonic bath (MUS) (B).

The chemical compositions and functional properties of both types of the extracted mucilage, either (MHW) or (MUS), are presented in Table 1. The extracted mucilage, with the aid of an ultrasonic bath, recorded protein and ash contents higher than those of the extracted MHW. This may be attributed to the fact that ultrasonic waves help disrupt plant cell walls, which improves the solvent penetration enhanced mass transfer across the cell membrane [28]. The ash value is an important parameter for detecting purity and the presence of other substances. The mucilage's lower ash value indicates its purity from the accompanying materials [29]. The MUS recorded higher values of the functional properties than MHW. These functional properties of the gel extracted from plant waste have great importance in determining the aspects of this gel's use in the industry. Naji et al. [30] determined the emulsifying and foaming characteristics of garden cress mucilage and observed that the garden cress mucilage possessed great emulsifying and foaming ability ( $92 \%$ and $25.4 \%$, respectively) at $250 \mathrm{C}$. Also, it was revealed that cress seed mucilage was a superior emulsifier than gum acacia [31]. Moniri et al. [32] reported that freeze-dried garden cress mucilage possessed high emulsifying capacity and stability (> 80\%).

Table 1. Chemical composition and function properties of the two types of mucilage.

\begin{tabular}{l|c|c} 
Composition & MHW & MUS \\
\hline Moisture \% & $14.9 \pm 0.46$ & $12.9 \pm 0.45$ \\
\hline Protein \% & $31.2 \pm 0.75$ & $34.1 \pm 0.79$ \\
\hline Oil \% & 0.0 & 0.0 \\
\hline Ash \% & $11.34 \pm 0.65$ & $13.46 \pm 0.5$ \\
\hline Functional properties & & \\
\hline Water holding capacity\% & $1153 \pm 10$ & $1210 \pm 15$ \\
\hline Oil holding capacity\% & $144 \pm 5$ & $180 \pm 6$ \\
\hline Foaming capacity\% & $16 \pm 0.29$ & $26 \pm 0.69$
\end{tabular}




\begin{tabular}{l|c|c} 
Composition & MHW & MUS \\
\hline Foaming stability after 2hours\% & $10 \pm 0.5$ & $21 \pm 0.6$ \\
\hline Bulk density g/cm & $0.61 \pm 0.1$ & $0.56 \pm 0.1$ \\
\hline Emulsion stability\% & $85 \pm 0.5$ & $82 \pm 0.5$
\end{tabular}

The values are expressed as the means \pm SD.

As illustrated in Table 2, both types of the extracted mucilage (MUS and MHW) had approximately the same contents of minerals. Singh and Paswan [33] and Prajapati and Dave [34] showed that garden cress seed contains considerable amounts of potassium and calcium.

Table 2. The mineral content of the two types of mucilage expressed as mg/g dry weight.

\begin{tabular}{l|c|c} 
Minerals & MHW $(\mathbf{m g} / \mathbf{g})$ & MUS $(\mathbf{m g} / \mathbf{g})$ \\
\hline Copper & $0.032 \pm 0.001$ & $0.033 \pm 0.001$ \\
\hline Iron & $0.079 \pm 0.001$ & $0.132 \pm 0.001$ \\
\hline Zinc & $0.047 \pm 0.001$ & $0.049 \pm 0.001$ \\
\hline Manganese & $0.026 \pm 0.001$ & $0.041 \pm 0.001$ \\
\hline Sodium & $1.576 \pm 0.02$ & $1.229 \pm 0.01$ \\
\hline Magnesium & $8.300 \pm 0.1$ & $7.980 \pm 0.1$ \\
\hline Potassium & $18.395 \pm 0.2$ & $17.580 \pm 0.2$ \\
\hline Calcium & $5.710 \pm 0.2$ & $6.140 \pm 0.1$
\end{tabular}

The values are expressed as the means \pm SD.

As shown in Table 3, both types of the extracted mucilage (either with hot water or with the aid of an ultrasonic bath) had potent antioxidant activity. However, The MUS exhibited higher radical scavenging activity than that of the MHW and even higher than the antioxidant butylated hydroxytoluene (BHT). The superiority of the extracted mucilage with the aid of ultrasonic bath as an antioxidant may be due to ultrasonic wave effects on the cell's hydrolysis, facilitating the disruption of cell wall liberating protein and sugar, which may cause considerable interference in these antioxidant activity assays. Alkahtani et al. [35] found that garden cress mucilage exhibited radical scavenging activity. Omer et al. [36] and Singh and Paswan [33] reported that garden cress seed fractions exposed scavenging activity versus 1, 1diphenyl-2-picrylhydrazyl (DPPH) radical and good Ferric Reducing Antioxidant Power (FRAP). So, it acts as in vivo and in vitro antioxidant.

Table 3. Antioxidant activity of $1 \%$ the two types of mucilage compared to BHT.

\begin{tabular}{l|c|c} 
Samples & DPPH \% & FRAP mg/g \\
\hline MHW & $61.3^{\mathrm{a}} \pm 0.49$ & $15.6^{\mathrm{b}} \pm 0.29$ \\
\hline MUS & $88.9^{\mathrm{b}} \pm 0.88$ & $18.2^{\mathrm{c}} \pm 0.48$ \\
\hline BHT & $63.7^{\mathrm{a}} \pm 0.79$ & $7.5^{\mathrm{a}} \pm 0.25$
\end{tabular}

Dissimilar superscript letters in the same column denote significant differences at $p<0.05$. The values are expressed as the means $\pm \mathrm{SD}$

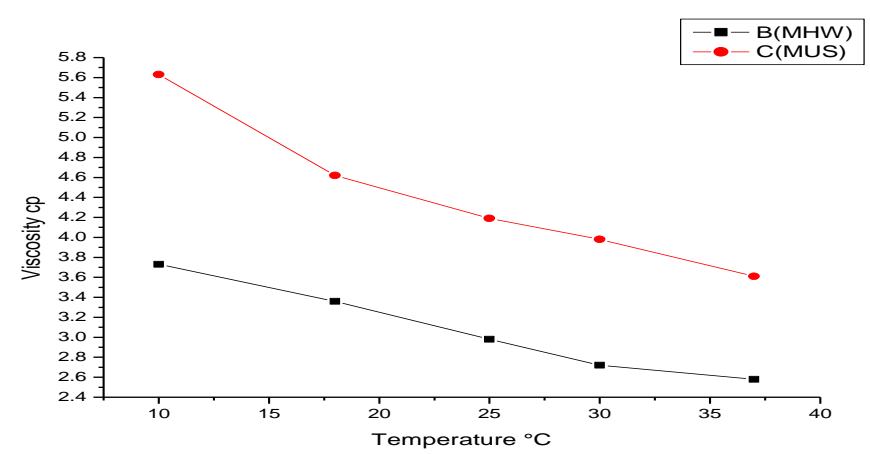

Figure 3. Effect of temperature on viscosity of the two types of mucilage. 
As shown in Figure 3, with the increasing temperature, the viscosity also decreases with the increasing rpm, the viscosity decreases as illustrated in Figure 4. It was observed that the extracted MUS was more viscous than the extracted MHW, which was also confirmed through the high value of water holding capacity of MUS as declared before in Table 1.

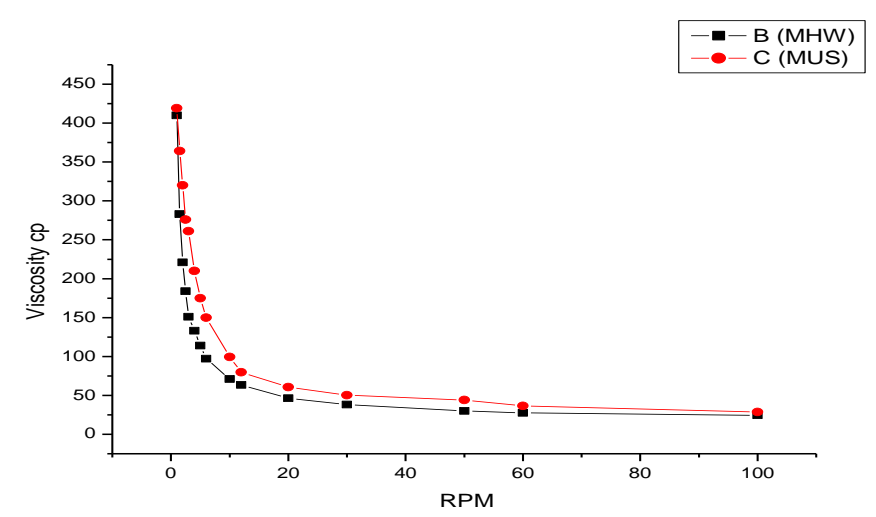

Figure 4. Effect of rpm on the viscosity of 1:100 (w/v) of MHW and MUS.

The FTIR spectrum (Figure 5) shows no difference in composition between both types of the extracted mucilage (either with hot water or with the aid of an ultrasonic bath). The FTIR spectrum shows the same functional groups related to constitutes of the mucilage, such as protein and carbohydrates. The O-H stretching and $\mathrm{N}-\mathrm{H}$ group appears at 3430, 3427, and 2926 $\mathrm{cm}^{-1}$, respectively. Further, the C-H aliphatic appears at $2885,2857 \mathrm{~cm}^{-1}$. The peak is shown at the wavenumbers 1741 and $1738 \mathrm{~cm}^{-1}$ corresponding to the $-\mathrm{C}=\mathrm{O}$ group. Similar findings were obtained by Moniri et al. [37]. The peaks at 1123 and $1033 \mathrm{~cm}^{-1}$ denote the monosaccharides such as glucose and mannose, as confirmed by a previous study [38]. The fingerprint district for carbohydrates is between wavenumbers 800 and $1200 \mathrm{~cm}^{-1}$. Amid (N$\mathrm{H})$ group indicates the presence of protein [37].

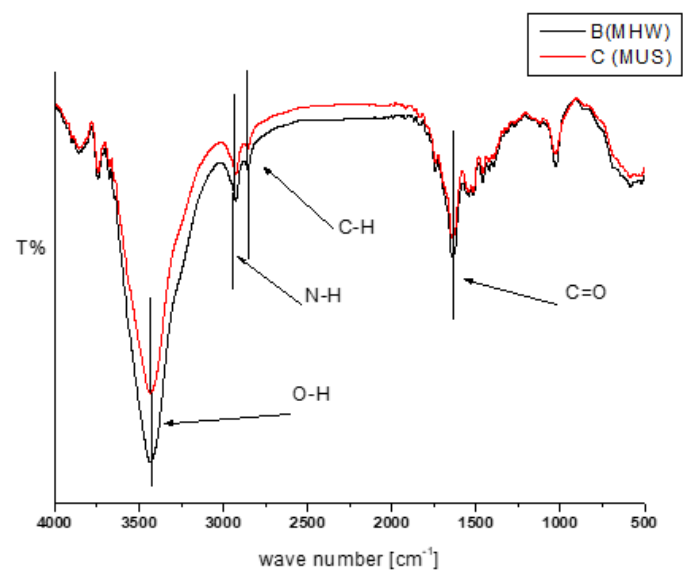

Figure 5. FTIR spectra of both MHW and MUS.

The garden cress mucilage extracted by ultrasonic waves was non-toxic for normal cell lines and didn't produce a change in cells' viability within the studied concentration $(0.78$ $100 \mu \mathrm{g} / \mathrm{ml})$.

Non-steroidal anti-inflammatory drugs, such as indomethacin, are well known to cause gastrointestinal damage either in rats or humans. The long-term NSAIDs treatment is known to cause mucosal injuries of the small intestine, among them bleeding, erosion, and ulcers [39]. 
In the current results, there were non-significant changes in the weight gain and total food intake of the three studied groups after the first week of the study (Figure 6 and 7). The 7 days treatment with indomethacin produced a significant reduction in weight gain and total food intake. Previous studies found that indomethacin administration caused a significant reduction in weight gain and total food intake [3, 40]. Rats pre-treated with the garden cress mucilage recorded total food intake and body weight gain significantly higher than rats treated with indomethacin only.

As evident from Table 4, a decrease in the final body weight gain, although not statistically significant, was recorded by the rats treated with indomethacin when compared with the normal rats. It was reported in previous studies that the treatment with indomethacin resulted in shortening of the small intestine length [3,41]. So, the small intestine length was measured in the current study. It was found that rats treated with indomethacin recorded less small intestine length. The small intestine length of the rats pre-treated with the garden cress mucilage was approximately near that of the normal rats.

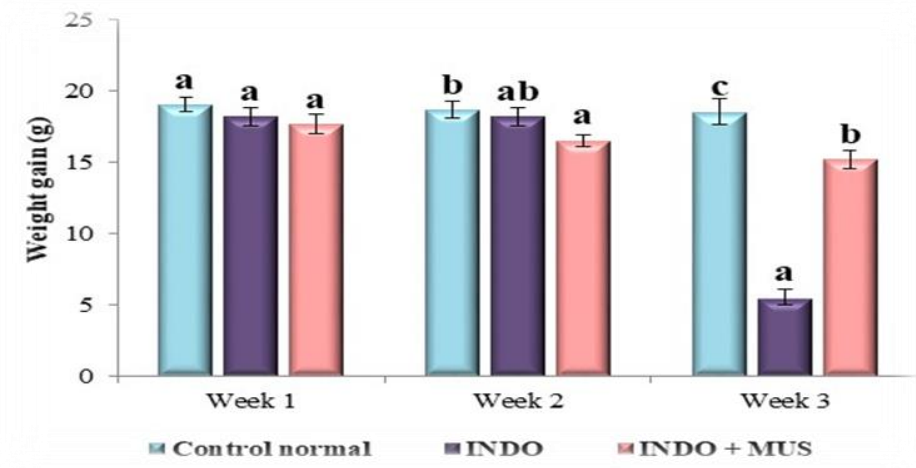

Figure 6. The weekly body weight gain of normal rats and rats treated with indomethacin. The values are expressed as the means \pm SE. $(n=6)$. Dissimilar superscript letters on each bar denote a significant difference at $\mathrm{P} \leq 0.05$. INDO, indomethacin; MUS, mucilage extracted by the ultrasonic bath.

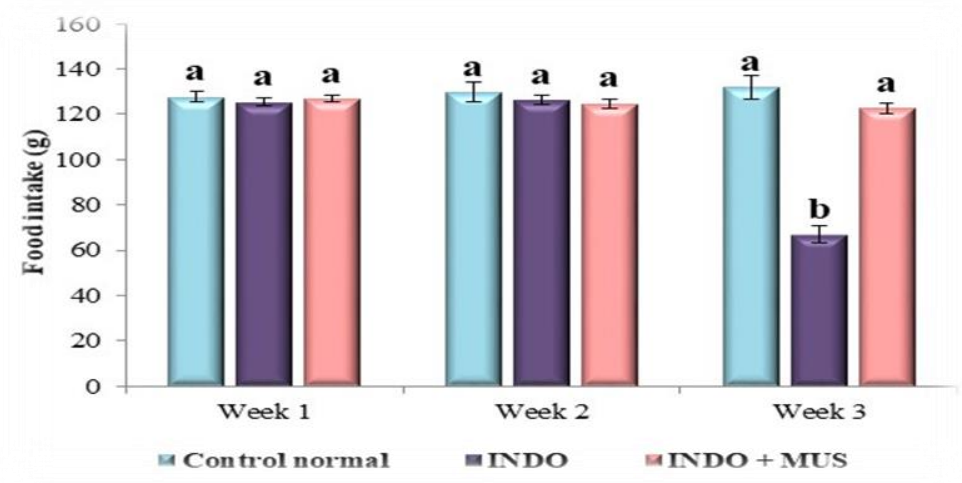

Figure 7. The weekly total food intake of normal rats and rats treated with indomethacin. The values are expressed as the means \pm SE. $(n=6)$. Dissimilar superscript letters on each bar denote a significant difference at $\mathrm{P} \leq 0.05$. INDO, indomethacin; MUS, mucilage extracted by the ultrasonic bath.

Table 4. Effect of the garden cress mucilage on the growth performance parameters.

\begin{tabular}{l|c|c|c}
\multirow{2}{*}{ Parameters } & \multicolumn{3}{|c}{ Groups } \\
\cline { 2 - 4 } & Control normal & INDO & MUS + INDO \\
\hline Initial body weight $(\mathbf{g})$ & $234.50^{\mathrm{a}} \pm 2.81$ & $234.33^{\mathrm{a}} \pm 7.27$ & $234.50^{\mathrm{a}} \pm 7.35$ \\
\hline Final body weight $(\mathbf{g})$ & $290.67^{\mathrm{a}} \pm 3.27$ & $276.17^{\mathrm{a}} \pm 6.89$ & $0.83^{\mathrm{a}} \pm 7.39$ \\
\hline Feed efficiency ratio & $0.14^{\mathrm{a}} \pm 0.01$ & $0.13^{\mathrm{a}} \pm 0.01$ & 80.01 \\
\hline Small intestine length $(\mathbf{c m})$ & $83.58^{\mathrm{b}} \pm 1.05$ & $72.67^{\mathrm{a}} \pm 1.05$ & $80.75^{\mathrm{b}} \pm 1.30$
\end{tabular}

The values are expressed as the means \pm SE. $(n=6)$. Dissimilar superscript letters in each row denote a significant difference at $\mathrm{P} \leq 0.05$. INDO, indomethacin; MUS, mucilage extracted by the ultrasonic bath. 
As shown in Table 5, the concentration of hemoglobin decreased significantly in the rats treated with indomethacin. However, the intestinal hemoglobin increased significantly in the rats treated with indomethacin. In addition to the impairment of iron absorption, the blood loss, subsequent to the treatment with NSAID, leads to anemia. Also, the hemorrhage is associated with small intestine inflammation subsequent to NSAID treatment [42]. The intestinal hemoglobin was found to be decreased in rats pre-treated with garden cress mucilage, which indicated garden cress mucilage's role in preventing bleeding after the treatment with indomethacin. Also, ESR and LDH activity increased significantly in the rats treated with indomethacin compared with the normal rats. Elevation of LDH activity in the current results is coinciding with Shu et al. [43], who confirmed the release of LDH due to indomethacininduced cell damage. The pre-treatment with garden cress mucilage prevented the elevation of ESR and LDH activity significantly. There were non-significant differences in iron and TIBC values between the groups.

Table 5. Effect of the garden cress mucilage on the blood biochemical parameters and intestinal hemoglobin.

\begin{tabular}{l|c|c|c}
\multirow{2}{*}{ Parameters } & \multicolumn{3}{|c}{ Groups } \\
\cline { 2 - 4 } & Control normal & INDO & MUS + INDO \\
\hline Hemoglobin $(\mathbf{g} / \mathbf{d l})$ & $12.81^{\mathrm{b}} \pm 0.56$ & $11.24^{\mathrm{a}} \pm 0.22$ & $12.04^{\mathrm{a}} \pm 0.21$ \\
\hline Iron $(\mathbf{m g} / \mathbf{d l})$ & $237.69^{\mathrm{a}} \pm 11.12$ & $235.77^{\mathrm{a}} \pm 6.16$ & $236.15^{\mathrm{a}} \pm 8.28$ \\
\hline TIBC $(\boldsymbol{\mu g} / \mathbf{d l})$ & $66.26^{\mathrm{a}} \pm 1.39$ & $69.82^{\mathrm{a}} \pm 0.88$ & $66.71^{\mathrm{a}} \pm 1.43$ \\
\hline ESR $(\mathbf{m m} / \mathbf{h})$ & $2.83^{\mathrm{a}} \pm 0.31$ & $7.67^{\mathrm{b}} \pm 0.80$ & $3.00^{\mathrm{a}} \pm 0.26$ \\
\hline LDH (U/I) & $268.03^{\mathrm{a}} \pm 8.28$ & $322.89^{\mathrm{b}} \pm 7.12$ & $286.55^{\mathrm{a}} \pm 4.53$ \\
\hline $\begin{array}{l}\text { Intestinal Hemoglobin } \\
(\mathbf{m g} / \mathbf{1 0 0 m l})\end{array}$ & $4.05^{\mathrm{a}} \pm 0.22$ & $87.59^{\mathrm{a}} \pm 1.05$ & $6.74^{\mathrm{b}} \pm 0.56$
\end{tabular}

The values are expressed as the means \pm SE. $(n=6)$. Dissimilar superscript letters in each row denote a significant difference at $\mathrm{P} \leq 0.05$. INDO, indomethacin; MUS, mucilage extracted by the ultrasonic bath; TIBC, total ironbinding capacity; ESR, erythrocyte sedimentation rate; LDH, lactate dehydrogenase.

NSAIDs interact with the intestinal phospholipids, which cause damage to the intestinal cells and increase gastrointestinal permeability. The microvascular blood flow is reduced via COX inhibition, and aggressive luminal agents alter and amplify this reaction, causing inflammation, erosions, and ulcers. Acid, bile, and bacteria in the small bowel are the main luminal aggressors [39]. It was mentioned in a previous study that mucilage could attenuate oxidative stress and inflammation, which may be attributed to the positive effect of mucilage on gut microbiota [26]. On the one hand, the treatment with indomethacin in the current study resulted in an elevation of intestinal MDA, NO and TNF- $\alpha$ and a reduction in intestinal GSH and SOD as shown in Table 6. On the other hand, the pre-treatment with garden cress mucilage suppressed the elevation of intestinal MDA, NO, and TNF- $\alpha$. Also, the pre-treatment with garden cress mucilage reversed the reduction in intestinal GSH and SOD. Oxidative stress and inflammation subsequent to administration of indomethacin had been reported in previous studies since activation of inducible nitric oxide synthase (iNOS) and production of nitric oxide (NO) is associated with intestinal lesions subsequent to administration of NSAIDs [3, 44]. Santiago-López et al. [45] also reported that treatment with indomethacin increased TNF- $\alpha$ and other cytokines' values. The antioxidant activity of garden cress mucilage contributed to the suppression of elevation of intestinal MDA and reduction of intestinal GSH and SOD. Ahmad et al. [7] reported that polysaccharides extracted from garden cress reduced the level of tumor necrosis factor-alpha (TNF- $\alpha$ ) in mice's plasma. Thus, the protective effect of garden cress mucilage against indomethacin-induced enter-colitis may be attributed to its role in preventing oxidative stress and inflammation after administration of indomethacin. 
Table 6. Effect of the garden cress mucilage on the small intestine' biochemical parameters.

\begin{tabular}{l|c|c|c}
\multirow{2}{*}{ Parameters } & \multicolumn{3}{|c}{ Groups } \\
\cline { 2 - 4 } & Control normal & INDO & MUS + INDO \\
\hline MDA (nmol/g tissue) & $15.59^{\mathrm{a}} \pm 0.98$ & $34.62^{\mathrm{b}} \pm 2.87$ & $17.25^{\mathrm{a}} \pm 0.74$ \\
\hline NO (umol/g tissue) & $50.99^{\mathrm{a}} \pm 1.52$ & $81.56^{\mathrm{b}} \pm 3.65$ & $52.33^{\mathrm{a}} \pm 1.58$ \\
\hline GSH (mg/g tissue) & $22.88^{\mathrm{c}} \pm 0.47$ & $18.49^{\mathrm{a}} \pm 0.54$ & $20.35^{\mathrm{b}} \pm 0.37$ \\
\hline SOD (U/g tissue) & $6.50^{\mathrm{c}} \pm 0.21$ & $4.16^{\mathrm{a}} \pm 0.17$ & $5.95^{\mathrm{b}} \pm 0.15$ \\
\hline TNF- $\boldsymbol{\alpha}$ (pg/g tissue) & $10.33^{\mathrm{a}} \pm 0.38$ & $21.63^{\mathrm{c}} \pm 0.34$ & $12.95^{\mathrm{b}} \pm 0.57$
\end{tabular}

The values are expressed as the means \pm SE. $(n=6)$. Dissimilar superscript letters in each row denote a significant difference at $\mathrm{P} \leq 0.05$. INDO, indomethacin; MUS, mucilage extracted by the ultrasonic bath; MDA, malondialdehyde; NO, nitric oxide; GSH, reduced glutathione; SOD, superoxide dismutase; TNF- $\alpha$, tumor necrosis factor-alpha.

\section{Conclusions}

The ultrasound was the highly efficient mucilage extraction method due to its positive effect on the protein content and functional properties. The mucilage extracted from garden cress seeds meal as a natural nutraceutical exhibited potent antioxidant activity. The mucilage extracted with the aid of an ultrasonic bath was higher in the antioxidant power. The mucilage extracted with an ultrasonic bath's aid prevented the elevation of the erythrocyte sedimentation rate, intestinal tumor necrosis factor- $\alpha$, and plasma lactate dehydrogenase activity. Also, rats administrated with the mucilage recorded lower intestinal malodealdehyde and higher intestinal reduced glutathione. Therefore, the mucilage extracted with the aid of an ultrasonic bath may be useful in preventing enter-colitis.

\section{Funding}

This research was funded by National Research Centre, grant number E120404.

\section{Acknowledgments}

This research has no acknowledgment.

\section{Conflicts of Interest}

The authors declare no conflict of interest.

\section{References}

1. Porter, R.J.; Kalla, R.; Ho, G.T. Ulcerative colitis: Recent advances in the understanding of disease pathogenesis. F1000Research 2020, 9, https://doi.org/10.12688/f1000research.20805.1.

2. Kayal, M.; Shah, S. Ulcerative Colitis: Current and Emerging Treatment Strategies. Journal of Clinical Medicine 2020, 9, https://doi.org/10.3390/jcm9010094.

3. Cervantes-García, D.; Bahena-Delgado, A.I.; Jiménez, M.; Córdova-Dávalos, L.E.; Ruiz-Esparza Palacios, V.; Sánchez-Alemán, E.; Martínez-Saldaña M.C.; Salinas, E. Glycomacropeptide Ameliorates Indomethacin-Induced Enteropathy in Rats by Modifying Intestinal Inflammation and Oxidative Stress. Molecules 2020, 25, https://doi.org/10.3390/molecules25102351.

4. Nie, Y.; Lin, Q.; Luo, F. Effects of non-starch polysaccharides on inflammatory bowel disease. International journal of molecular sciences 2017, 18, https://doi.org/10.3390/ijms18071372.

5. Dixit Jr, I.V.; Kumar, I.; Palandurkar, K.; Giri, R.; Giri, K. Lepidium sativum: Bone healer in traditional medicine, an experimental validation study in rats. Journal of family medicine and primary care 2020, 9 , 812-818, https://doi.org/10.4103/jfmpc.jfmpc_761_19.

6. Golkar, P.; Hadian, F.; Dehkordi, M.K. Production of a new mucilage compound in Lepidium sativum callus by optimizing in vitro growth conditions. Natural product research 2019, 33, 130-135, https://doi.org/10.1080/14786419.2018.1437426. 
7. Ahmad, A.; Jan, B.L.; Raish, M.; Alkharfy, K.M.; Ahad, A.; Khan, A.; Ganaie, M.A.; Hamidaddin, M. Inhibitory effects of Lepidium sativum polysaccharide extracts on TNF- $\alpha$ production in Escherichia colistimulated mouse. 3 Biotech 2018, 8, https://doi.org/10.1007/s13205-018-1309-9

8. Taha, F.S.; Ibrahim, M.A. Effect of degree of hydrolysis on the functional properties of some oilseed proteins. Grasas Y Aceites 2002, 53, 273-281, https://doi.org/10.3989/gya.2002.v53.i3.317

9. Alfredo, V.O.; Gabriel, R.R.; Luis, C.G.; David, B.A. Physicochemical properties of a fibrous fraction from chia (Salvia hispanica L.). LWT - Food Science and Technology 2009, 42, 168-173, https://doi.org/10.1016/j.lwt.2008.05.012

10. Shahidi, F.; Han, X.Q.; Symwiecki, J. Production and characteristics of protein hydrolysates from capelin (Mallotus villosus). Food Chemistry 1995, 53, 285-293, https://doi.org/10.1016/0308-8146(95)93934-j.

11. Wang, Y.; Li, D.; Wang, L.J.; Li, S.J.; Adhikari, B. Effects of drying methods on the functional properties of flaxseed gum powders. Carbohydrate Polymers 2010, 81, 128-133, https://doi.org/10.1016/j.carbpol.2010.02.005.

12. AOAC. Official Methods of Analysis. $15^{\text {th }}$ Edn. Association of Official Analytical Chemists, Washington, DC. 2005.

13. Mosmann, T. Rapid colorimetric assay for cellular growth and survival: application to proliferation and cytotoxicity assays. Journal of immunological methods 1983, 65, 55-63, https://doi.org/10.1016/00221759(83)90303-4

14. Thabrew, M.I.; Hughes, R.D.; Farlane, I.G. Screening of hepatoprotective plant components using a HepG2 cell cytotoxicity assay. Journal of Pharmacy and Pharmacology 1997, 49, 1132-1135, https://doi.org/10.1111/j.2042-7158.1997.tb06055.x

15. Reeves, P.G.; Nielsen, F.H.; Fahey, G.C. AIN-93 Purified Diets for Laboratory Rodents: Final Report of the American Institute of Nutrition Ad Hoc Writing Committee on the Reformulation of the AIN-76A Rodent Diet. Journal of Nutrition 1993, 123, 1939-1951.

16. Drabkin, D.I. The standardization of heamoglobin measurements. The American Journal of Medical Sciences 1949, 21.

17. Stookey, L.L. Ferrozine-a new spectrophotometric reagent for iron. Analytical Chemistry 1970, 42, 779-781, https://doi.org/10.1021/ac60289a016.

18. Betts, C.A.; Stuart, B. Determination of serum total iron-binding capacity. Journal of Clinical Pathology 1973, 26, 457, https://doi.org/10.1136/jcp.26.6.457-a

19. Zimmerman, H.J.; Weinstein, H.G. Lactic dehydrogenase activity in human serum. Journal of Laboratory and Clinical Medicine 1956, 48, 607-616.

20. Crosby, W.H.; Furth, F.W. A Modification of the Benzidine Method for Measurement of Hemoglobin in Plasma and Urine. Blood 1956, 11, 380-383, https://doi.org/10.1182/blood.v11.4.380.380.

21. Schuck-Phan, A.; Phan, T.; Dawson, P.A.; Dial, E.J.; Bell, C.; Liu, Y.; Rhoads, J.M.; Lichtenberger, L.M. Formula Feeding Predisposes Gut to NSAID-Induced Small Intestinal Injury. Clinical \& experimental pharmacology 2016, 6, https://doi.org/10.4172/2161-1459.1000222

22. Ohkawa, H.; Ohishi, N.; Yagi, K. Assay for lipid peroxides in animal tissues by thiobarbituric acid reaction. Analytical Biochemistry 1979, 95, 351-358, https://doi.org/10.1016/0003-2697(79)90738-3

23. Montgomery, H.A.C.D.J.; Dymock, J.F. Determination of nitrite in water. Analyst 1961, 86.

24. Sedlak, J.; Lindsay, R.H. Estimation of total, protein-bound and nonprotein sulfhydryl groups in tissue with Ellman's reagent. Analytical Biochemistry 1968, 25, 192-205, https://doi.org/10.1016/0003-2697(68)900924.

25. Mohamed, D.A.; Abdelgayed, S.S.; Essa, H.A.; Mohamed, R.S. Preparation and Evaluation of functional foods for prevention of non-alcoholic fatty liver disease. Pakistan journal of biological sciences 2018, 21, 454-462, https://doi.org/10.3923/pjbs.2018.454.462.

26. Mohamed, D.A.; Mohamed, R.S.; Fouda, K. Anti-inflammatory potential of chia seeds oil and mucilage against adjuvant-induced arthritis in obese and non-obese rats. Journal of Basic and Clinical Physiology and Pharmacology 2020, 1, https://doi.org/10.1515/jbcpp-2019-0236.

27. Akhtar, M.N.; Mushtaq, Z.; Ahmad, N.; Khan, M.K.; Ahmad, M.H.; Hussain, A.I.; Imran, M. Optimal Ultrasound-Assisted Process Extraction, Characterization, and Functional Product Development from Flaxseed Meal Derived Polysaccharide Gum. Processes 2019, 7, https://doi.org/10.3390/pr7040189.

28. Kumar, M.; Tomar, M.; Potkule, J.; Verma, R.; Punia, S.; Mahapatra, A.; Belwal, T.; Dahuja, A.; Joshi, S.; Berwal, M.K.; Satankar, V.; Bhoite, A.G.; Amarowicz, R.; Kaur, C.; Kennedy, J.F. Advances in the Plant Protein Extraction: Mechanism and Recommendations. Food Hydrocolloids 2021, 115, https://doi.org/10.1016/j.foodhyd.2021.106595.

29. Husain, M.; Wadud, A.; Sofi, G.; Perveen, S.; Hafeez, K.A. Physicochemical standardization of mucilage obtained from Althaea officinalis Linn-Root. Pharmacognosy Magazine 2019, 15, 155-161.

30. Naji, S.; Razavi, S.M.A.; Karazhiyan, H. Effect of freezing on functional and textural attributes of cress seed gum and xanthan gum. Food and Bioprocess Technology 2013, 6, 1302-1311, https://doi.org/10.1007/s11947-012-0811-z.

31. Patel, M.M.; Chauhan, G.M.; Patel, L.D. Mucilages of Lepidium sativum Linn. (Asario) and Ocimum canum. Sims. (Bavchi) asemulgents. Indian Journal of Hospital Pharmacy 1987, 24, 200-202. 
32. Moniri, H.; Farahmandfar, R.; Motamedzadegan, A. Cress seed (Lepidium sativum) gum dried by vacuum, freeze, and microwave drying methods: Structural, rheological, emulsifying, and foaming properties. Journal of Food Process Engineering 2020a, 43, https://doi.org/10.1111/jfpe.13408.

33. Singh, C.S.; Paswan, V.K. The potential of garden cress (Lepidium sativum L.) seeds for development of functional foods. In: Advances in Seed Biology. 2017; https://doi.org/10.5772/intechopen.70355.

34. Prajapati, M.R.; Dave, P.H. Therapeutic and nutritional importance of garden cress seed. Journal of Pharmacognosy and Phytochemistry 2018, 7, 140-143.

35. Alkahtani, J.; Elshikh, M.S.; Almaary, K.S.; Ali, S.; Imtiyaz, Z.; Ahmad, S.B. Anti-bacterial, anti-scavenging and cytotoxic activity of garden cress polysaccharides. Saudi Journal of Biological Sciences 2020, 27, 29292935, https://doi.org/10.1016/j.sjbs.2020.08.014

36. Omer, A.B.; Nour, A.H.; Ali, M.M.; Ishag, O.A.O.; Erwa, I.Y.; Ali, M.A. Phytochemical Screening, Antimicrobial and Antioxidant Activity of Lepidium sativum Seeds Extract. South Asian Research Journal of Natural Products 2020, 3, 10-17.

37. Moniri, H.; Farahmandfar, R.; Motamedzadegan, A. Investigation of hot air and foam-mat dried cress seed gum by FT-IR, zeta potential, steady shear viscosity, dynamic oscillatory behavior, and other physical properties. Food science \& nutrition 2020b, 8, 2143-2155, https://doi.org/10.1002/fsn3.1514

38. Han, Y.L.; Gao, J.; Yin, Y.Y.; Jin, Z.Y.; Xu, X.M.; Chen, H.Q. Extraction optimization by response surface methodology of mucilage polysaccharide from the peel of Opuntiadillenii haw. fruits and their physicochemical properties. Carbohydrate Polymers 2016, 151, 381-391, https://doi.org/10.1016/j.carbpol.2016.05.085.

39. Kim, T.J.; Kim, E.R.; Hong, S.N.; Kim, Y.H.; Lee, Y.C.; Kim, H.S.; Kim, K.; Chang, D.K. Effectiveness of acid suppressants and other mucoprotective agents in reducing the risk of occult gastrointestinal bleeding in non-steroidal anti-inflammatory drug users. Scientific Reports 2019, 9, https://doi.org/10.1038/s41598-01948173-6.

40. Kawashima, R.; Tamaki, S.; Kawakami, F.; Maekawa, T.; Ichikawa, T. Histamine H2-Receptor Antagonists Improve Non-Steroidal Anti-Inflammatory Drug-Induced Intestinal Dysbiosis. International journal of molecular sciences 2020, 21, https://doi.org/10.3390/ijms21218166.

41. Monteros, M.J.M.; Galdeano, C.M.; Balcells, M.F.; Weill, R.; De Paula, J.A.; Perdigón, G.; Cazorla, S.I. Probiotic lactobacilli as a promising strategy to ameliorate disorders associated with intestinal inflammation induced by a non-steroidal anti-inflammatory drug. Scientific Reports 2021, 11, https://doi.org/10.1038/s41598-020-80482-z.

42. Chamoun-Emanuelli, A.M.; Bryan, L.K.; Cohen, N.D.; Tetrault, T.L.; Szule, J.A.; Barhoumi, R.; WhitfieldCargile, C.M. NSAIDs disrupt intestinal homeostasis by suppressing macroautophagy in intestinal epithelial cells. Scientific reports 2019, 9, 1-15, https://doi.org/10.1038/s41598-019-51067-2.

43. Shu, R.; Wang, C.; Meng, Q.; Liu, Z.; Wu, J.; Sun, P.; Sun, H.; Ma, X.; Huo, X.; Liu, K. Resveratrol enhances the protective effects of JBP485 against indomethacin-induced rat intestinal damage in vivo and vitro through up-regulating oligopeptide transporter 1 (Pept1). Biomedicine \& Pharmacotherapy 2019, 111, 251261, https://doi.org/10.1016/j.biopha.2018.12.084.

44. Jung, E.S.; Jang, H.J.; Hong, E.M.; Lim, H.L.; Lee, S.P.; Kae, S.H.; Lee, J. The Protective Effect of 5Aminosalicylic Acid against Non-Steroidal Anti-Inflammatory Drug-Induced Injury through Free Radical Scavenging in Small Intestinal Epithelial Cells. Medicina 2020, 56, https://doi.org/10.3390/medicina56100515.

45. Santiago-López, L.; Hernández-Mendoza, A.; Vallejo-Cordoba, B.; Mata-Haro, V.; Wall-Medrano, A.; González-Córdova, A.F. Milk fermented with Lactobacillus fermentum ameliorates indomethacin-induced intestinal inflammation: An exploratory study. Nutrients 2019, 11, https://dx.doi.org/10.3390\%2Fnu11071610. 